\title{
The Image of the Family and Family Home in Małgorzata Musierowicz's Series of Novels, and the Stereotype of the Family in Contemporary Polish Society
}

\author{
Joanna Senderska ${ }^{1}$ (D) Iwona Mityk ${ }^{1}$ (D) $\cdot$ Ewa Piotrowska-Oberda ${ }^{1}$ (D)
}

Accepted: 15 April 2021 / Published online: 11 May 2021

(c) The Author(s) 2021

\begin{abstract}
The article discusses the image of the family and the family home in a series of novels for young people by the popular Polish writer Małgorzata Musierowicz in the context of literary conventions and stereotypes about the family in contemporary Polish society. The novels, which cover a period of over 40 years, generally fit contemporary Polish realities; however, the didactic function of the novels results in the author creating an idealized image of the Polish intellectual family, filling the readers with optimism. The picture created by the writer, on the one hand, fits perfectly into the stereotype of the family, which is one of the values highly esteemed by Poles. On the other hand, it adapts to the conventions of novels for girls. In this article, the stereotype of the family is reconstructed on the basis of language data and surveys. We present the meanings and contexts of family as a noun and family as an adjective. We also present the results of our survey, the aim of which was to determine an essence of a stereotypical family and how the traditional family model is comprehended by respondents coming from various groups. We also present the respondents' attitude to the patriarchal family model and the division of roles into male and female. In our opinion, the correspondence between the family picture created in the novels and the image of the family operating in social consciousness is the reason for the popularity of the series.
\end{abstract}

Keywords Małgorzata Musierowicz $\cdot J e \dot{z} y c j a d a \cdot$ Young-adult novels $\cdot$ Stereotypical family $\cdot$ Family $\cdot$ Family home

Handling Editor: Victoria de Rijke

\footnotetext{
Joanna Senderska is a linguist and speech therapist. She is mainly interested in Polish syntax and contemporary lexis.

Iwona Mityk is a specialist in literary studies. Her research interests lie in contemporary Polish literature.

Ewa Piotrowska-Oberda is a linguist, English language translator and interpreter.
}

Extended author information available on the last page of the article 


\section{Introduction}

The family and the family home are essential parts of human life. It is difficult to overestimate their influence on the formation of character and the direction of a person's life. It is no wonder that this subject is often discussed in literature intended for young readers, who grow up in a family environment.

The goal of this article is to discuss the image of family life presented in Jeżycjada, a multi-volume series of novels for young people by Małgorzata Musierowicz. The author of the saga is one of the most respected authors of works for children and teenagers in contemporary Polish literature. The most well-known component of her writing is the Jeżycjada series. While discussing the image of the family in Jeżycjada, we draw attention to the following problems:

- the image of the family in relation to its stereotype,

- the image of the family in relation to literary convention,

- the image of the family in relation to the image of the family in contemporary Polish youth literature.

\section{Literary Works of Małgorzata Musierowicz}

In 1977, Musierowicz published the first novel of the Jeżycjada titled Szósta klepka. In 1982, the third book of the series, Kwiat kalafiora, made the IBBY Honour List. In 2005, the fifteenth novel, Jezzyk Trolli, was added the White Raven Internationale Jugendbibliothek List in Munich. The success of the series, which now includes 22 novels published over 43 years, means that individual books have been reprinted many times due to its enormous popularity among readers (Frycie, 2002, p. 7; Leszczyński, 2007, p. 121). The ability to follow the lives of readers' favourite protagonists, members of the Borejko family, over many years has played an important role in the series' popularity. Its significance for Polish culture can be compared to the series by Lucy Maud Montgomery about Anne Shirley. In 2008, Małgorzata Musierowicz was awarded the Lifetime Achievement Medal by the Polish Section of IBBY. Her novels have been translated into German, Italian, Swedish, Czech, Lithuanian, Hungarian, Bulgarian, Slovenian, Vietnamese, and Japanese.

Musierowicz's literary work has been discussed in both press reviews and academic articles. Literary scholars discuss the issues of the relationship between the protagonists' family home and the outside world (Szargot, 2001; Gomóła, 2002), the functioning of the characters in the school environment (Gomóła, 2001), the reflection of contemporary life in the world presented in the novel, and the characters' attitude to cultural tradition (Sznigier, 2004). They indicate the difficulty of presenting the routine of everyday life (Leszczyński, 2007) as well as its metaphysical dimension (Mityk and Senderska, 2019).

Books have been devoted to her works. They include elaborations of individual novels (Kątny, 1996; Włodek, 2001; Jędrych, 2018), perceptions of specific phenomena therein, e.g., humour and linguistic comedy (Maczunder, 2000), and 
the reality of the novel (Czachowska and Szczerba, 2004). There have also been cross-sectional and monographic studies (Biedrzycki, 1999; Frycie, 2002; HeskaKwaśniewicz, 2003; Gomóła, 2004; Dakowicz, 2008; Szargot and Szargot, 2011). Appreciation of Musierowicz's series is also evidenced by its inclusion in the Dictionary of children's and youth literature (Tylicka and Leszczyński, 2003): in addition to the writer's biography, a separate entry is devoted to Jeżycjada.

Regarding the latest novels of the series, however, there are criticisms about excessive conservatism and programmatic avoidance of topics such as abortion, same-sex relationships and premarital sex, and, generally, for excessive detachment from the changing reality (e.g. Buczak, 2007; Piątek, 2013; Szybowicz, 2013a, b). The voices of critics are joined by the voices of readers who accuse her, inter alia, of repeated patterns, unreliability, and the promotion of anti-feminist and anti-liberal values (Mochocka, 2017, p. 94).

\section{Family as a Value Highly Appreciated by Poles}

The particular novels that compose Jeżycjada describe the twists and turns of teenagers' lives in the Jeżyce district of Poznan, from which she took the name of the series. Most of the leading teenage protagonists come from the Borejko family, members of the Polish intelligentsia. Hence, the critics often describe the series as a family saga. Perhaps the popularity of the series is due to the interest in and value Poles place on the family. This opinion is supported by a variety of studies, such as the one conducted by Jerzy Bartmiński and Stanisława Niebrzegowska-Bartmińska (2015) from 1985 to 2010 and the social cohesion study of the Central Statistical Office in 2015 (Bieńkuńska and Piasecki, 2017).

However, Poles do not always mean the same thing when they use the word family, as indicated by, among others, the research of Iwona Bielińska-Gardziel (2009). Bielińska-Gardziel reconstructs the common stereotype of the family as rooted in social consciousness using dictionary and survey data. This stereotype belongs to colloquial language, corresponding to the cultural common ground (van Dijk, 2003). Cultural common ground is the foundation for all intra- and intergroup knowledge. For a given culture, the common ground is unquestionable, reasonable and therefore, non-ideological. In other words, general norms and values shared by all representatives of a given culture form the common cultural base (van Dijk, 2003, p. 9).

We follow Bartmiński's (2007) understanding of stereotypes as stabilized, i.e., reproduced not temporarily created connections consolidated in collective memory at the specific level of lexemes. They are subjectively determined object representations which include not only the value characteristics of that image (and certainly not only negative, as stereotypes are commonly believed to be) but also its descriptive characteristics; they are also the result of the interpretation of reality within social cognitive models (Bartmiński, 1998). Such a broad understanding of a stereotype is justified as the concept of a stereotype presented by Hilary Putnam (1975), for whom a stereotype is a conventional image of an object about how it looks like, works, etc., and without which the meaning and use of words cannot be 
fully assimilated. Such an understanding of the stereotype does not oppose linguistic or formal stereotypes to mental stereotypes, but rather connects them.

Stereotypes, thus understood, are elements of one's linguistic worldview (Bartmiński, 2007). Stereotyping is inseparable from natural language, which is based on the subjective categorization of phenomena as well as convention and repetition. Stereotypes are, therefore, necessary elements of a common language and a common culture. The linguistic worldview consists of, among other things, specific characteristics of objects in which fixed images are combined with evaluations and patterns of behaviour. Analysis of the data allows us? to reconstruct these images, and to determine how language users interpret reality, which features people, things or concepts they notice, enhance, and prioritize.

Colloquially, the family is associated with the family atmosphere that prevails in it: "pleasant and warm'1 (Bańko, 2000, vol. 2, p. 454). The family shelters its members, gives them a sense of security, which is confirmed by expressive connections: family warmth (Bańko, 2000, vol. 1, p. 192); family hearth 'a family home or family, especially when we have in mind the sense of security connected with them' (Bańko, 2000, vol. 1, p. 1142), and the expression: as in a family, i.e. 'friendly, cordially' (Müldner-Nieckowski, 2003, p. 655).

The semantics of the concept of the family is inscribed with a strong positive evaluation; however, linguistic data indicates that the image of the family is not exclusively positive. Indications that families experience crises and that mutual living is difficult are conveyed in such expressions, among others, the conflicted family (Zgółkowa, 2002, p. 142); family troubles, family disputes (Skorupka, p. 38); or to wash a family's dirty linen in public meaning to 'discuss intimate family affairs, usually unpleasant, with strangers' (Doroszewski) and a current saying with an ironic twist: family pictures are safer than a family business, or, 'it is not advised to do business with a family because it usually fails' (Zgółkowa, 2002, p. 142).

The presence of a positive family image in the minds of Poles was confirmed by the results of surveys conducted in 1990 and 2000 by a team of linguists from Maria Curie-Sklodowska University under the direction of Bartmiński. The one thousand respondents were students at Lublin universities. The surveys aimed to show how words related to values, including families, were understood by Poles, as well as to answer the question of whether these values change or are stable. The research confirmed the thesis of Michael Fleischer (2003) on the stability of Polish collective symbolism (Bartmiński, 2006).

We presume that one of the reasons of the popularity of the series Jeżycjada is similarity between the image of the family created by Musierowicz and the Polish stereotype of the family. Hence, we conducted an analogous survey in October 2020 to examine whether the family stereotype has changed recently and whether the family is still as important for Poles as they declared some years ago. One thousand, nine hundred and eleven respondents took part in the online survey. As many as $90 \%$ of the respondents claimed that the essence of a real family is determined by love, which guarantees a sense of security, as well as a warm atmosphere in the family.

\footnotetext{
1 All translations are ours.
} 
Respondents also write about mutual kindness, understanding, respect, emotional ties, etc. We deliberately use the adjective real to describe the heart of the family stereotype because stereotypes have modality, which corresponds to the common meaning of the word real (Quasthoff, 1973; Bartmiński, 2007). The expression real means 'such that should be' (cf. Bielińska-Gardziel, 2009).

The results of our research are consistent with the Lublin study. Respondents to that study, in both 1990 and 2000, also mention the social aspect of the family (living under one roof, bringing up children) and its community dimension (living together, talking together, etc.). Again, this aligns with our research, which confirms that the family belongs to those concepts that are firmly established in social awareness and are not easily changeable.

The overwhelming majority of those surveyed consider the traditional family to be a heterosexual relationship of a man and a woman, usually sacred under God, although sometimes just a formal agreement, without any indication of how the marriage was entered into. Only a few answers identify a family with the patriarchal family model, in which there are the traditional concepts of the female and male roles, and the head of the family is a man. As many as $72.1 \%$ of the respondents answered that a division into male and female roles should not take place in the family. The overwhelming majority of respondents $(88.9 \%)$ also believe that spouses or partners should make decisions together.

\section{The Image of the Family and Family Home in Contemporary Polish Literature for Young People}

In youth literature, the family and the family home have been the most important and most frequently used elements of the represented world. The family home is the center of the teenage protagonists' life. Perhaps due to the didactic function of much youth literature, the writer's goal can be, among other things, to indicate the right models and shape the socially desired attitudes of young readers (Leszczyński, 2007, pp. 21-30). Therefore, the family is often presented as an environment that provides support to teenagers, giving them a sense of security, and ensuring optimal conditions of their personal development (Skotnicka, 2002, pp. 86-89). Such an image of the family is created in Jeżycjada, although it should be added that families serving as anti-patterns are also depicted, e.g., the Lisiecki family. The father of the Lisiecki family works abroad, and the mother does not pay too much attention to her sons, uses corporal punishment, and only cares about providing them with a more prosperous existence. When a family does not function properly, it becomes an environment that destroys teenage protagonists (cf. Maria Józefacka Dziewczyna nie ludzie, Lotnica).

Respected Polish authors such as Irena Jurgielewiczowa, Krystyna Siesicka, Natalia Rolleczek, Anna Onichimowska, Ewa Nowacka, Marta Fox, and Dorota Terakowska have tried to maintain the image of the created world within a realistic representation. Contrary to Musierowicz, they include serious problems in their plots, e.g., teenagers' rebellion against the norms of coexistence established in the family (Natalia Rolleczek Kochana rodzinka i ja, Rodzinne ktopoty i ja), parents' divorce 
and, consequently, broken families (Irena Jurgielewiczowa Ten obcy, Krystyna Siesicka Jezioro osobliwości), and educational mistakes made by guardians or a lack of generational bonding (Irena Jurgielewiczowa Niespokojne godziny, Janina Zającówna Wesele mojej mamy). Gertruda Skotnicka (2002, p. 90) notes that in some novels of Jeżycjada there are also family conflicts, as happens in Opium $w$ rosole. Scotnicka also points out that such problems appearing in earlier novels for young people were toned down due to their drastic nature and because the authors were guided by the desire to protect the younger generation from the darker sides of life (Skotnicka, 2002, p. 86).

A reversal of this tendency in literature for young people has been noticed since the 1990s. Under the influence of socio-political changes that have resulted in moral changes, taboos in novels for young people have been abandoned. A spectacular manifestation of this in 1994 was Tomek Tryzna's novel Panna Nikt (Ostasz, 2008, p. 93). After moving to the city, the protagonist, Marysia, enters an unknown environment, becomes entangled in satanic rituals and sadomasochistic relationships with girls pretending to be her friends. After discovering that her "friends" have mocked her, drawing her into a game that makes her lose her identity, Marysia commits suicide.

There are also problems related to the lives of the main characters: Cold family relations and breakdowns, parents focused on acquiring material goods, and family life being undervalued (Maria Emilia Józefacka Ale numer!, Anna Onichimowska Samotne wyspy $i$ storczyk). There are more frequent manifestations of parents' domination or demanding attitude towards their children (Krystyna Siesicka Dziewczyna Mistrza Gry, Kinga Dunin Tabu). The role of the authoritarian parent is sometimes played by the mother, imposing her rules on the whole family (Ewa Nowacka As $w$ reckawie). In turn, the portrait of the father tyrannizing his offspring has been created, among others, by Kinga Dunin (Tabu, Obciach) and Marta Fox (Niebo $z$ widokiem na niebo).

The problem of premature and unexpected teenage pregnancy is often raised (Ewa Nowacka Małe kochanie, wielka miłość, Ewa Przybylska Dotyk motyla, Dorota Terakowska Ono, Marta Fox Magda.doc, Paulina.doc, Kinga Dunin Tabu). This motif also appears in Jezyk Trolli, a novel that is part of Jeżycjada.

In the novels of Kinga Dunin (Tabu, Obciach), in which there are many intertextual references to Jeżycjada, the image of the family is built in opposition to the image of the Borejko family: moral norms are treated as subjective and human gestures are distorted. Thus, the writings of Dunin and Musierowicz are sometimes situated at opposite poles (Wójcik-Dudek, 2008, p. 166). In Dunin's novels, there are two related families with different values. Marta's parents have liberal views, support each other, and love their children. Marta's father takes care of the house, her mother works and supports the family, while being a fulfilled woman. In contrast, Mark's parents are staunch Catholics and, at the same time, hypocrites, which is why they lack mutual understanding despite living by the adopted rules. The father is a domestic tyrant who decides everything and demands obedience from children.

Mostly, however, the vision of the family in YA novels is more optimistic: even the most serious problems can be solved in the family. This happens in novels by Barbara Ostrowicka, Świat do góry nogami and Niezwykłe wakacje or Janina 
Zającówna Tylko Kaśka, Uważajcie na skorpiony. A similarly positive vision of the family can be found in the novels of Natalia Osińska (Fanfik, Slash, Fluff), who was the first to introduce non-heteronormative protagonists to literature addressed to young people. Tosia, of Osińska's debut novel Fanfik (Fanfic), published in 2016, discovers at the age of 16 that she feels like a boy and decides to come out. She is brought up in an incomplete family, the role of her deceased mother is played by her overbearing sister. Tosia's father loves her, but is unable to establish contact with her, so he places the burden of raising his daughter on the shoulders of his sister-inlaw. However, when Tosia decides to transition, he supports her, as does her aunt, though not without hesitation.

A positive vision of a multi-generational family with many children, in which news of the mother's next pregnancy is welcomed and the children are brought up liberally, is created in the novel Lady of Kier by Maria Ewa Letka. The novel Agaton-Gagaton by Marta Fox is also full of optimism.

These examples show that it is not only the author of Jeżycjada who omits issues considered too serious or drastic for a young audience. The cheerful aura, so characteristic of Musierowicz's writing, is also present in the works of other authors and are classified analogically to the series in question as sagas or novels for girls, e.g., the above-mentioned Dama kier by Maria Ewa Letka or Czwarta kropka biedronki by Barbara Wiza.

\section{A Picture of the Family and Family Home in Jeżycjada}

In her series, Musierowicz refers primarily to the positive features of the family stereotype, and thus our ideas about what a real family should look like. In the family home of the Borejkos, who are the most important characters of this series, there is a nice, warm, atmosphere that gives a sense of security. As Jadwiga Ruszała points out, the value

[...] of the whole saga of this author is programmatic optimism, faith in the good and in self-fulfilment, praise for tolerance, and mutual kindness between the characters. In the Borejko family, these feelings are transferred to people staying with them. In the writer's assumption, home plays a stabilizing role in the lives of the protagonists, it provides support and a safe refuge, an important asylum for people of all ages. And this is the most important message of the novel, along with a lot of hope that the emotional needs of the characters will be fulfilled - therefore, also in the case of young readers during the difficult period of adolescence. (Ruszała, 2002, p. 154)

There is no doubt that both the atmosphere and the characters that compose it are idealized. The series presented by Musierowicz is addressed primarily to young adults, though the novels are eagerly read by more mature readers, who have been tracking the lives of the Borejko family since the days when they were teenagers. This type of novel is intended to teach the reader to follow certain patterns and, therefore, performs an educational function. (Leszczyński, 2007, pp. 110-121, Skotnicka, 2002, pp. 81-88). 
Readers accept the twists and turns experienced by the four characteristically different sisters belonging to the nice Borejko family-spontaneous Gabrysia, energetic Ida, subtle Natalia, and, the youngest, serene Patrycja-and the next generation, that of their children. The success of the first novels encouraged the writer to continue the characters' stories and to keep the books addressed to young adult readers. As a result, the author's attention has gradually moved to focus on the members of the next generation.

However, despite the educational function and the intentions to create a world with a thread of optimism, the series does not deviate very much from the reality of the times described in particular novels. The plots of Musierowicz's novel fit into contemporary Polish space-time realities, which are visible both in the main events and in the secondary characters in the background. This is why, in the first novels of Jeżycjada, there is a large-city family of two generations "with a father who works professionally and a mother who is the centre of family life" (Skotnicka, 2002, p. 81). As Skotnicka (2002, pp. 81-82) points out, it was the type of family most often chosen in novels for teenagers from the 1970s and 1980s, the prevalence of which is confirmed by sociological research. However, families in those novels usually had two children and were referred to as small. In this regard, Musierowicz slightly deviated from the applicable standard because the Borejko family in Kwiat kalafiora appears with four children, with an age range that is so large that the oldest girl, Gabrysia, is attending high school, while the youngest, Patrycja, is only a few years old. In later novels, with the birth of the children of the first protagonists, the Borejko's natural transition to a multigenerational family takes place.

Due to the long-term continuation of the series, the early works show the reality of the late 1970s, and the action of the later novels is set in the first years of the new century. Despite the stability of the family microcosm, the novels are focused on teenage problems of growing up. Each casts the teenage protagonists in the invariably cordial atmosphere of family relations, while the reality surrounding them is subject to the changes in Polish social life. For example, in the novel Kwiat kalafiora, one of the conversations among one of the Borejkos' families concerns the effectiveness of purchasing food in the emerging difficulties:

"Our unfortunate father will not be standing in the queue," Ida explained. "Pulpecja is the only one for conquering crowds." She meant five-year-old Patrycja, a sweet baby with a steel character, a typical bloom of the 1970s. This bloom could cry on call when the queue, pressing with a compact mass on the counter, demanded that all the elderly, pregnant women and invalids should be kept away, as should those with children in their arms. In such moments, seasoned in battle, the baby started to cry so convincingly that the detonated queue died down and there were no longer complaints about the big girl who should not have to be carried [...] (Musierowicz, 2003, p. 11)

Opium $w$ rosole hints at the martial law in Poland during the early 1980s, about which the author does not write directly due to censorship. However, the absence of some of the fathers, which is emphasized in the narrative, clearly suggests to readers that they were arrested, which affects the experiences of teenage protagonists. Later novels deal with issues of social life, such as the establishment of 
private small businesses (Patrycja's husband turns out to be such an enterprising young man) or the growing role of the mass media.

Writing about Czarna Polewka, one of the subsequent novels, Grzegorz Leszczyński, emphasizes the value that Musierowicz in Jeżycjada places on realistic elements: "The ordinariness of the world, human problems, ordinary home and peer environments, family. This ordinariness arouses interest, it is harder to write about ordinariness, without resorting to fancy plot constructions." (Leszczyński, 2007, p. 68)

The author places the Borejko parents in the traditional roles of mother and father, which is particularly evident in the first novels of the series. They function according to a clearly outlined patriarchal pattern. Mila has given up her professional career, and she is staying at home organizing everyday family life and taking care of her four daughters. Her husband, Ignacy Borejko, is depicted as a man primarily involved in his professional work, which absorbs so much of his attention that he learns about the adventures of his daughters with some delay. Ignacy's passion for reading contributes to his absent-mindedness: as a classical philologist, he is constantly lost in the world of books.

When his wife unexpectedly is hospitalized due to illness, his eldest daughter, teenage Gabrysia, despite her young age and lack of knowledge about running a household, has to manage both the duties previously performed by her mother and continue her school education. The excess of responsibilities causes her mental burnout, and only these difficulties cause him to become more involved in the home. Despite the author's appointing the father as the head of the family, Ignacy exhibits a specific helplessness in the area of everyday existence, resulting in part from customs specific to his generation that divide household duties into female and male activities and in part from his character. In later novels in the series, the grey routine of everyday life remains quite distant from him, but he observes family problems more closely, reacting to them in his specific way, which is not devoid of distraction.

Thus, Musierowicz uses moral patterns functioning in Polish society in the 1970s, as well as traditional stereotypes of female and male roles. These stereotypes, however, are more clearly outlined in the Żak or Kowalik families appearing in the background in the novels. Ignacy Borejko, as the head of the family, does not fully correspond to the type of strict patriarchal parent. He is not a dominant person who, by an absolute imperative, would force his children to behave in a way that he considers to be right. For the remaining family members, what is important is his quiet presence and companionship, sometimes silence, and sometimes even clumsiness, through which he constitutes a specific point of support due to his noble ethical attitude.

The person on whom the entire organization of family existence relies is, contrary to appearances, his quiet and calm but resourceful wife. It is Mila Borejko who is the real pillar of the house. Her gentleness is combined with resoluteness and, at the same time, common sense and cordiality. As a result, her daughters look to her for understanding and help in times of crisis. In Kalamburka, it appears that Mrs. Borejko is no longer satisfied with the role of housewife and grandmother alone because she begins writing, which leads to her plays being staged (admittedly under a pseudonym) in the theatre. 
Despite the problems they encounter, Musierowicz's heroines most often stand out for their strong character, courage, and independence. An exception to these figures is the sensitive, ethereal Natalia, whose silhouette best matches the set of features stereotypically ascribed to women. They are enumerated by Kamila Budrowska in her analysis of modern Polish prose: "emotionality, willingness to sacrifice for others, gentleness, sensitivity to the feelings and needs of others, warmth in relations with others, caring, submissiveness, difficulty in making decisions." (Budrowska, 2000, p. 81)

Male characters usually remain in the background, which may be associated with the fact that the novels are primarily addressed to girls, but which also may result from Polish tradition. During the difficult period of the partitions in the 19th century and the national uprisings that followed, the role of women increased and they had to demonstrate greater independence to ensure the existence of their family.

In Jeżycjada, a significant symbol of strong family ties is the gathering of household members at a common table or the family tradition of drinking tea and other drinks from blue cups. These simple gestures trigger a sense of community, mutual acceptance, understanding, and a sense of security against external threats, which is quickly taken over by new members of the family: "And Gabrysia and Grzegorz sat at the table smiling, drinking tea and holding hands. And then they looked at funny slogans and inscriptions stuck to the wall above the table [...] and placed on a shelf, along a row of blue mugs, photographs." (Musierowicz, 2007, p. 185)

When the Borejko home is mentioned, it does not refer to a flat, but the people who live in it. Their kindness, compassion, and sense of humor mean that they are perceived by friends or random characters as kind-hearted and good people, and that is why others are attracted to them:

Everyone who stayed in it for even half an hour went out full of appreciation for its coziness, beauty, and indefinite grace, which breathed here in every corner. It was not realized that every apartment of this family would have similar features and that the feeling of coziness was not born in the living room furniture or carpets. It was just cozy with these people-poor, helpless, and unpretentious. This is why the guests of the Borejkos stayed longer than it was appropriate, and many of them stayed up late into the night, although tea and bread with jam were often the only refreshments. (Musierowicz, 2003, p. 14)

The cordial, warm atmosphere in this family's home attracts others and encourages them to stay with them. This is why the Borejko family is eagerly visited by both good friends and random characters. An example is the little Aurelia Jedwabińska in Opium $w$ rosole, who does not find this aura in her own home, which her father abandoned and to which her strict mother returns late from work. Elka Stryba has similarly positive feelings towards the protagonists when she finds herself in their apartment. At the time she does not suspect that Gabrysia is the future wife of her widowed father, about whom she had learned only a few hours earlier:

Elka's heart went to her. She certainly would not know how to put that feeling into words-because, so far, she did not need to specify her feelings. It was something like longing, that Gabrysia would prepare something so 
carefully for her, that she would take care of her, wipe her head with a towel or even rebuke her with her strong, warm, joking voice. They do not even know how lucky they are that they have such a mother! she thought reluctantly about Pyza and Tygrysek [...] (Musierowicz, 2007, p. 144)

As one of the researchers of Musierowicz's work, Stanisław Frycie, notes:

The immanent feature of the writer's prose is optimism in life, a positive attitude towards the world and people, tolerance and understanding. In Jeżycjada, Musierowicz creates an image of intellectual families that support the traditional model of life. Although these are not families overflowing with luxuries, they have an unusual atmosphere, which means that difficulties and life's complications do not lead to increased aggressiveness or alienation but bring household members closer together. (Frycie, 2002, p. 30)

The climate of cordial family ties also attracts readers who react to the problems and adventures of the novel's characters. They try to contact the author and provide ideas for solving them. This happens, for example, when Natalia is choosing the right life partner. Joanna Szczęsna mentions this phenomenon, writing that young readers

demanded ("I strongly demand that you bring them back together. Robrojek plus Natalia - no! The reaction is not taking place") and appealed to conscience and higher feelings ("If Nutria has to marry Robrojek, please have mercy and don’t let Filip be hurt"). [...] Czesław Miłosz also turned out to be a supporter of Robrojek. (Szczęsna, 2001)

In the Borejko family, the four sisters have very strong family ties. They take care of each other in difficult moments, even into adult life, when they have already started their own families. In the tenth novel of the Nutria i Nerwus series, a distracted Natalia tries to help older Gabriela, who is ill, organize a holiday for her two daughters Róża and Laura. She does this even though she has other plans, and she is not comfortable in the responsible role of babysitter. In turn, Gabriela and Ida are worried about Natalia when she goes on holiday and try to help her as much as possible, despite the distance between them.

Some of the decisions made by members of the Borejko family are surprising to the readers, such as when Ida, as an adult, lives in the basement of the building where her parents live. This is because basements are not a place intended for living in Poland. However, this decision can be interpreted more in psychological terms than in material terms (although for a young married couple of doctors who are just beginning their careers, finances might have been a consideration) because it is associated with the aura of safety orbit exerted by the family. Later, this situation also acquires a practical dimension when the energetic Ida's two children are born. Ida does not think about slowing down the pace of her professional career, much less about stopping it, because her grandparents can babysit without major commuting problems. 
The Borejkos also fulfil the traditional family model because they constitute a complete family circle in which no parents are missing. However, this is not always duplicated in the lives of other characters. Political accidents, trips to Western Europe, divorce, and the death of parents, often results in incomplete family units for the other characters. This is the case, for example, in the novel Opium $w$ rosole, in which one of the main characters, Aurelia, is painfully affected by the divorce of her parents, and the other, Janina Krechowicz, has to live in another city with her grandfather because her parents are arrested during martial law. In the novel Córka Robrojka, the title character, Bella Rojek, despite her mother's early death, does not feel the consequences of bereavement thanks to her father's prudent upbringing. Instead, she grows into a reasonable and resourceful person:

She was cheerful and sincere by nature. She was full of energy, but also prudence. She was enthusiastic about everything — whether it was about moving a wardrobe or digging through the garden, foreign languages, or the struggles of the East. She could repair the washing machine, clean the carburettor, replace a windowpane, or change a car tyre. Her father taught her many things needed in life so that she would not have to ask for favours from anyone so that she would be independent. (Musierowicz, 2000, p. 42)

In creating the storyline of the next generation, progressive moral changes are visible. Apart from the youngest of the Borejko sisters, Patrycja, all the others experience more turbulent lives. In other words, their relationships with their partners no longer fully fulfil the parents' marital model of a lasting relationship according to the model of a romance novel with a clear division into female and male roles. Gabriela, with her two little daughters, is abandoned by her first husband, who breaks off contact with them completely. She finds happiness in her next marriage a few years later, symptomatically, by choosing a partner somewhat similar to her father. Natalia experiences the greatest love troubles among the sisters because, in each new fiancé, she sooner or later sees a person who wants to dominate her in one way or another, which means that she struggles with the feeling of being trapped after an initial state of infatuation. Only calm, prudent Robert Rojek, a schoolmate of Gabrysia's, meets her expectations for a sense of stability and security, without being constrained by excessive expectations. Natalia-with Robert, his teenage daughter Bella, and the two sons from her and Robert's marriage-finally creates a happy family, but it is a so-called patchwork family. This is similar to her sister Gabrysia's family, which includes her two daughters from her first marriage, her second husband Grzegorz Stryba, and their son.

The creation of Bella's character most clearly reflects the progressive social changes:

Bella Rojek from the novel Córka Robrojka is a typical representative of the young generation at the turn of the century. She dresses in sporty clothes, practices karate, knows how to grow roses, fixes the plumbing, repairs creaky doors, sews, cooks, and gives first aid. Using Bella's example, it is clear that at the end of the 20th century there are no typical male activities-women have 
become independent from men and cope with the difficulties of everyday life very well. (Sznigier, 2004, p. 124)

The property status of the Borejkos reflects the average standard of living in the country, according to the reality of the time to which it refers. It is not a wealthy family, but the author does not use this within the framework of a realistic convention, but rather, she creates their world according to a fairy-tale convention for the adolescent audience and intended didactic impact. Most of the protagonists of Jeżycjada, like the heroes of fairy tales, highly value spirituality and emotional ties, while material objects do not play a major role in their lives. The solutions to the problems that arise with the development of the plot suggest that, in Musierowicz's novels, it is primarily the support of another person and not the material status of the characters, that is important. In subsequent novels, the Borejkos are often described by the writer as rather poor, and family members, although they do not suffer poverty, make purchases with caution. They only indulge in buying books, which emphasizes their tendency to cultivate intellectual behaviour. In some of the later novels, affluence turns out to be negative, resulting in emotionally bereft characters, as happens, for example, in the novel, Córka Robrojka, set in the mid-1990s and the beginning of the development of capitalism in Poland. In the novel, one of the supporting characters, who is nouveau riche, employs his former friend, Robert Rojek, to exploit him as a relatively cheap workforce.

\section{Conclusion}

In her series, Małgorzata Musierowicz manages to create an intriguing circle of protagonists who are linked by strong, cordial family ties, in which lies their strength. She achieved this effect thanks to the use of an attractive idealized family model, which she places in a setting that does not significantly deviate from contemporary realities. Therefore, young readers are actively involved in the lives of the characters, the more so as the lives of their favorite protagonists do not come to complete closure, which would be inevitable with a single work, but (and in the literature for young people this happens rarely) they are developed for several dozen years in following novels. And although some novels contain family conflicts, as happens in Opium $w$ rosole or Dziecko piatku in the Jedwabiński house, they remain in the background without obscuring the endearing picture of warm relations in the Borejko family.

The phenomenon of the continuous popularity of Musierowicz's series seems to result, among other things, from the fact that it does not show a typical family, but a stereotypical family, what a family should be, which is consistent with the ideas of most Poles. And it does not matter that, especially in the first novels of the series, the patriarchal model of the family is presented, with more or less traditionally understood division of spouses' roles, despite Ignacy Borejko's awkwardness and reservedness. Despite the negative aspects of the "archaic", as some respondents wrote in our surveys, the family model is balanced by the cordial atmosphere and love in the Borejko home. This makes subsequent generations of readers reach for both old and 
new novels of the series, sometimes getting angry about an anachronistic division of roles to escape from a reality that is not always friendly.

Due to the large temporal span of her literary venture, the writer (despite endeavours that distinguish some of the novels, such as Kalamburka), does not avoid the danger of repeating a plot pattern or duplicating a character's storyline. However, the optimistic tone of the novels and the adoption of clear literary conventions imprisoned the author within their framework. Hence, the formal criteria adopted at the beginning of the series, entailing a specific canon of attitudes and character behaviour, include a delineation of the boundaries of the issues raised, among which being that nothing would introduce too dark an atmosphere. The criteria only allowed for a certain retouching of previous assumptions, which is manifested, for example, in the fact that the mother started writing or by showing cultural differences in introducing the Oracabess family, whereas some young readers would expect further actions reflecting changing social customs.

The fact that at least some teenagers want to read books reflecting moral and social changes is evidenced by, for example, the popularity of Natalia Osińska's writing. She meets the expectations of many young readers and deals with topics that have so far been ignored in youth literature, such as same-sex relationships or transgenderism. This subject is often raised by young fan fiction creators and is popular among young people. The author herself admits that she wanted to write a book that could reach as many young people as possible. (Komender, 2017). The writer also takes into account the voices of readers, e.g., constructing the plot of the new novels of the series about queer teenagers from Poznań (Kobus, 2019). Osińska's novels are sometimes perceived as consciously referring to Musierowicz's novels, even polemical towards them (Mochocka, 2017; Szybowicz, 2018). The writer, however, rejects such comparisons (Komender, 2017; Ulańska, 2018).

Małgorzata Musierowicz's values, reflected in her novels, appears constant, but the circle of her possible readers has partially changed. The writer certainly notices it, but she cannot (or does not want to?) radically change her views to draw the majority of the current generation of teenagers to her work.

Author Contributions All authors contributed to the study conception and design. Material preparation, data collection and analysis were performed by Iwona Mityk, Ewa Piotrowska-Oberda and Joanna Senderska. The first draft of the manuscript was written both by Iwona Mityk and Joanna Senderska, who dealt with different sections of the manuscript. All authors commented on previous versions of the manuscript. All authors read and approved the final manuscript.

Funding No funding was received to assist with the preparation of this manuscript.

Availability of Data and Material (Data Transparency) Not applicable.

Code Availability (Software Application or Custom Code) Not applicable.

\section{Declarations}

Conflict of interest All authors certify that they have no affiliations with or involvement in any organization or entity with any financial interest or non-financial interest in the subject matter or materials discussed in this manuscript. 
Open Access This article is licensed under a Creative Commons Attribution 4.0 International License, which permits use, sharing, adaptation, distribution and reproduction in any medium or format, as long as you give appropriate credit to the original author(s) and the source, provide a link to the Creative Commons licence, and indicate if changes were made. The images or other third party material in this article are included in the article's Creative Commons licence, unless indicated otherwise in a credit line to the material. If material is not included in the article's Creative Commons licence and your intended use is not permitted by statutory regulation or exceeds the permitted use, you will need to obtain permission directly from the copyright holder. To view a copy of this licence, visit http://creativecommons.org/licen ses/by/4.0/.

\section{References}

Bańko, Mirosław (Ed.). (2000). Inny stownik języka polskiego. Warszawa: WN PWN.

Bartmiński, Jerzy. (1998). Podstawy lingwistycznych badań nad stereotypem na przykładzie stereotypu matki. Język a Kultura, 12, 63-83.

Bartmiński, Jerzy (Ed.). (2006). Język - wartości - polityka. Zmiany rozumienia nazw wartości w okresie transformacji ustrojowej w Polsce. Raport z badań empirycznych. Lublin: Wydawnictwo UMCS.

Bartmiński, Jerzy. (2007). Stereotypy mieszkaja w języku. Studia etnolingwistyczne. Lublin: Wydawnictwo UMCS.

Bartmiński, Jerzy and Niebrzegowska-Bartmińska, Stanisława. (2015). Nie ma (prawdziwej) wolności bez odpowiedzialności. O kontrowersjach wokót pojęcia wolności. In Urszula Sokólska (Ed.), Odkrywanie słowa - historia i wspótczesność (pp. 13-38). Białystok: Wydawnictwo UwB.

Biedrzycki, Krzysztof. (1999). Małgorzata Musierowicz i Borejkowie. Kraków: Universitas.

Bielińska-Gardziel, Iwona. (2009). Family and its profiles in contemporary Polish. In Jerzy Bartmiński and Rosemarie Lühr (Eds), Europa und seine Werte. Akten der internationalen Arbeitstagung Normen- und Wertbegriffe in der Verständigung zwischen Ost- und Westeuropa (pp. 121-140). Frankfurt am Main: Peter Lang GmbH.

Bieńkuńska, Anna and Piasecki, Tomasz (Eds). (2017). Jakość życia w Polsce w 2015 roku. Wyniki badania spójności społecznej. Warszawa. Accessed October 8, 2020 from https://stat.gov.pl/obszary-temat yczne/warunki-zycia/dochody-wydatki-i-warunki-zycia-ludnosci/jakosc-zycia-w-polsce-w-2015-rokuwyniki-badania-spojnosci-spolecznej,4,2.html.

Buczak, Dominika. (2007, December 2). Małgorzata Musierowicz skacze przez rekina. Gazeta Wyborcza. Accessed October 20, 2020 from https://wyborcza.pl/1,76842,4710458.html

Budrowska, Kamila. (2000). Kobieta i stereotypy. Obraz kobiety w prozie polskiej po roku 1989. Białystok: Trans Humana.

Czachowska, Kinga and Szczerba, Dorota. (2004). Poznań Borejków. Spacer z bohaterami powieści Małgorzaty Musierowicz. Poznań: Media Rodzina.

Dakowicz, Przemysław (Ed.). (2008). Moja Musierowicz. O twórczości autorki Jeżycjady. Łódź: Wydawnictwo WSHE.

Doroszewski, Witold (Ed.). (2000). Stownik języka polskiego. CD. Warszawa: WN PWN.

Fleischer, Michael. (2003). Stabilność polskiej symboliki kolektywnej. In Jerzy Bartmiński (Ed.), Język w kręgu wartości (pp. 107-143). Lublin: Wydawnictwo UMCS.

Frycie, Stanisław. (2002). Małgorzata Musierowicz. Warszawa: Wydawnictwo WSP TWP.

Gomóła, Anna. (2001). Nauczyciele i szkoła w powieściach Małgorzaty Musierowicz. In Dorota Michułka (Ed.), Przeboje edukacji polonistycznej (pp. 75-90). Wrocław: WUWr.

Gomóła, Anna. (2002). Wybrane aspekty proksemicznych standardów życia rodzinnego w powieściach Małgorzaty Musierowicz. In Joanna Papuzińska and Grzegorz Leszczyński (Eds.), Kultura literacka dla dzieci i młodzieży u progu XXI stulecia (pp. 156-166). Warszawa: CEBID.

Gomóła, Anna. (2004). Saga rodu Borejków. Kulturowe konteksty Jeżycjady. Katowice: Wydawnictwo UŚ.

Heska-Kwaśniewicz, Krystyna (Ed.). (2003). Między „Bambolandia” i „Jeżycjada”. Małgorzaty Musierowicz makro- $i$ mikrokosmos. Katowice: Wydawnictwo UŚ.

Jędrych, Karolina. (2018). Przesunięcie centrum świata i ucieczka na wieś w Febliku i Wnuczce do orzechów Małgorzaty Musierowicz. Annales Universitatis Paedagogicae Cracoviensis. Studia Poetica., 6, 52-63.

Kątny, Marek. (1996). Kłamczucha. Kwiat kalafiora Małgorzaty Musierowicz, Kielce: Gens.

Kobus, Aldona. (2019, May 9). „Fluff” angstem podszyty. Wywiad z Natalią Osińską. Szuflada.net. Accessed February 19, 2021 from http://szuflada.net/fluff-angstem-podszyty-wywiad-z-natalia-osinska/ 
Komender, Dominika. (2017). Dlaczego polskie nastolatki zaczytują się w historiach o gejowskich związkach? Accessed February 14, 2021 from https://www.vice.com/pl/article/3dd8vw/dlaczego-polsk ie-nastolatki-zaczytuja-sie-w-historiach-o-gejowskich-zwiazkach

Leszczyński, Grzegorz. (2007). Magiczna biblioteka. Zbójeckie książki młodego wieku, Warszawa: CEBID.

Maczunder, Halina. (2000). Humor i komizm sytuacyjny w wybranych powieściach Małgorzaty Musierowicz. Warszawa: Elipsa.

Mityk, Iwona, and Senderska, Joanna. (2019). Przejawy metafizyki codzienności w wybranych tomach Jeżycjady Małgorzaty Musierowicz. Studia Filologiczne UJK, 32, 39-50.

Mochocka, Aleksandra. (2017). Two Perspectives on the Performative Social Body: Teenage Make-up Routines in Fanfik and the Jeżycjada cycle. Miscellanea Posttotalitariana Wratislaviensia, 7, 87-115.

Müldner-Nieckowski, Piotr. (2003). Wielki stownik frazeologiczny języka polskiego. Warszawa: Świat Książki.

Musierowicz, Małgorzata. (2000). Córka Robrojka. Łódź: Akapit Press.

Musierowicz, Małgorzata. (2003). Kwiat kalafiora. Łódź: Akapit Press.

Musierowicz, Małgorzata. (2007). Noelka. Łódź: Akapit Press.

Ostasz, Maria. (2008). Proza dziecięco-młodzieżowa w drugiej połowie XX stulecia. Annales Academiae Paedagoicae Cracoviensis. Studia ad Bibliothecarum Scientiam Pertinentia, 6, 89-104.

Piątek, Tomasz. (2013, January 18). McDuszno. Gazeta Wyborcza. Accessed November 3, 2020 from https:// krytykapolityczna.pl/archiwum/felietony-archiwalne/tomasz-piatek/mcduszno/2013/

Putnam, Hilary. (1975). Mind, Language and Reality. Philosophical Papers. Vol. 2. Cambridge: Cambridge University Press.

Quasthoff, Uta M. (1973). Soziales Vorurteil und Kommunikation. Eine sprachwissenschaftliche Analyse des Stereotyps. Frankfurt am Main: Athenäum Verlag.

Ruszała, Jadwiga. (2002). Saga rodu Borejków, czyli przesłanie nadziei. In Małgorzata Musierowicz (Ed.), Stanistaw Frycie (pp. 153-154). Warszawa: Wydawnictwo WSP TWP.

Skorupka, Stanisław. (1989). Słownik frazeologiczny języka polskiego, vol. 2. Warszawa: Wiedza Powszechna.

Skotnicka, Gertruda. (2002). Jaka jesteś polska rodzino? (o współczesnej beletrystyce dla dzieci i młodzieży). In Joanna Papuzińska and Grzegorz Leszczyński (Eds.), Kultura literacka dla dzieci $i$ młodzieży $u$ progu XXI stulecia (pp. 79-98). Warszawa: CEBID.

Szargot, Barbara. (2001). Dom i świat w powieściach Małgorzaty Musierowicz. In Dorota Michułka (Ed.), Przeboje edukacji polonistycznej (pp. 61-73). Wrocław: WUWr.

Szargot, Barbara and Szargot, Maciej. (2011). Jeżycjada a sprawa polska. O powieściach Małgorzaty Musierowicz. Katowice: Śląsk.

Szczęsna, Joanna. (2001, June 6). Małgorzata Musierowicz, Jeżycjada. Gazeta Wyborcza. Accessed February 15, from https://wyborcza.pl/1,153803,301519.html.

Sznigier, Maria. (2004). Współczesność i tradycja w wybranych powieściach Małgorzaty Musierowicz. Stupskie Prace Filologiczne. Seria Filologia Polska, 2, 123-129.

Szybowicz, Eliza. (2013a, February 11). Była fanka czyta Musierowicz. Krytyka Polityczna. Accessed October 31, 2020 from https://krytykapolityczna.pl/kultura/czytaj-dalej/byla-fanka-czyta-musierowicz/

Szybowicz, Eliza. (2013b, October 23). Musierowicz jest w złym humorze. Gazeta Wyborcza. Accessed October 31, 2020 from https://wyborcza.pl/1,75410,14831981,Musierowicz_jest_w_zlym_humorze_ tekst_z_Ksiazek_html

Szybowicz, Eliza. (2018, April 24). Na Jeżycach i na Marsie. Krytyka Polityczna. Accessed February 19, 2021 from https://krytykapolityczna.pl/kultura/czytaj-dalej/na-jezycach-i-na-marsie/

Tylicka, Barbara, and Leszczyński, Grzegorz. (2003). Słownik literatury dziecięcej i młodzieżowej. Wrocław: Ossolineum.

Ulańska, Zofia. (2018, May). Rozmowa z Natalią Osińską. Od empatii do akceptacji. Mały Format. Accessed February 19, 2021 from http://malyformat.com/2018/05/od-empatii-do-akceptacji-rozmowa-z-nataliaosinska/

van Dijk, Teun A. (2003). Dyskurs polityczny i ideologia. Etnolingwistyka. Problemy Języka i Kultury, 15, 7-8.

Włodek, Julia. (2001). Kwiat kalafiora. Warszawa: Nasza Księgarnia.

Wójcik-Dudek, Małgorzata. (2008). Czytajaca dziewczyna. O przemianach wspótczesnej powieści dla dziewczat. In Krystyna Heska-Kwaśniewicz (Ed.), Literatura dla dzieci i młodzieży (po roku 1980) (pp. 158-178). Katowice: Wydawnictwo UŚ.

Zgółkowa, Halina. (2002). Praktyczny słownik wspótczesnej polszczyzny, vol. 36. Poznań: Kurpisz. 
Publisher's Note Springer Nature remains neutral with regard to jurisdictional claims in published maps and institutional affiliations.

\section{Authors and Affiliations}

\section{Joanna Senderska ${ }^{1}\left[\right.$ - Iwona Mityk ${ }^{1}\left(\mathbb{0} \cdot\right.$ Ewa Piotrowska-Oberda ${ }^{1}$}

$\triangle$ Joanna Senderska

jsenderska@ujk.edu.pl; joanna.senderska@gmail.com

Iwona Mityk

iwona.mityk@ujk.edu.pl

Ewa Piotrowska-Oberda

ewa.oberda@gmail.com

1 Institute of Linguistics and Literary Studies, Jan Kochanowski University, Uniwersytecka 17, 25-406 Kielce, Poland 